Article

\title{
Associations between B Vitamins and Parkinson's Disease
}

\section{Liang Shen}

Shandong Provincial Research Center for Bioinformatic Engineering and Technique, School of Life Sciences, Shandong University of Technology, Zibo 255049, China; E-Mail: shen@sdut.edu.cn; Tel./Fax: +86-533-278-2220

Received: 3 July 2015 / Accepted: 20 August 2015 / Published: 27 August 2015

\begin{abstract}
B vitamins may correlate with Parkinson's disease (PD) through regulating homocysteine level. However, there is no comprehensive assessment on the associations between PD and B vitamins. The present study was designed to perform a meta-analytic assessment of the associations between folate, vitamin B6, and vitamin B12 and PD, including the status of B vitamins in PD patients compared with controls, and associations of dietary intakes of B vitamins and risk of PD. A literature search using Medline database obtained 10 eligible studies included in the meta-analyses. Stata 12.0 statistical software was used to perform the meta-analysis. Pooled data revealed that there was no obvious difference in folate level between PD patients and healthy controls, and PD patients had lower level of vitamin B12 than controls. Available data suggested that higher dietary intake of vitamin B6 was associated with a decreased risk of $\mathrm{PD}$ (odds ratio $(\mathrm{OR})=0.65,95 \%$ confidence intervals $(C I)=(0.30,1.01))$, while no significant association was observed for dietary intake of folate and vitamin B12 and risk of PD. PD patients had lower level of vitamin B12 and similar level of folate compared with controls. Dietary intake of vitamin B6 exhibited preventive effect of developing PD based on the available data. As the number of included studies is limited, more studies are needed to confirm the findings and elucidate the underpinning underlying these associations.
\end{abstract}

Keywords: Parkinson's disease; B vitamins; dietary intake; meta-analysis

\section{Introduction}

Parkinson's disease (PD) is a geriatric neurodegenerative disorder with increasing global prevalence resulting in tremors, rigidity, and bradykinesia [1-3]. Although the mechanisms underlying the dopaminergic neurons degeneration in PD remain obscure, oxidative stress has been widely accepted 
to play a prominent role [4,5]. Homocysteine (Hcy) is a sulfur-containing metabolite generated in the essential amino acid methionine cycle. Hcy exhibits multiple neurotoxic effects involved in the pathogenesis of several neurodegenerative disorders, including dementia, Alzheimer's disease and PD [6-8]. In recent years, many studies have investigated the associations between Hcy and PD and supported that patients with PD have increased levels of Hcy in comparison with age-matched healthy controls [9-13]. Increased levels of Hcy may lead to dopaminergic cell death in PD patients through neurotoxic effect [14-16] and thus, regulation of Hcy metabolism might decrease the risk of PD through decreasing plasma Hcy.

As methionine synthesis from Hcy requires B vitamins as cofactors, high B vitamins intake will decrease plasma Hcy level and may exert preventive effects of developing PD. However, to the best of our knowledge, there is no comprehensive assessment on the associations between PD and B vitamins. Thus, the present study was designed to comprehensively assess: (i) the B vitamins status in PD patients and controls; and (ii) efficacy of dietary intakes of B vitamins in lowering risk of PD, through meta-analyzing the available literatures. Levodopa is the most effective drug in the symptomatic management of PD and it was found that plasma Hcy levels are elevated in patients treated with levodopa. Thus, the meta-analyses of levodopa treated or untreated PD patients and controls were performed separately.

\section{Methods}

\subsection{Literature Search}

With the following search terms "Parkinson's disease" and "B vitamins" or "folate" or "folic acid" or "vitamin B6" or "vitamin B12" or "cobalamin", a literature search was performed in Medline database from inception until February 2015. To avoid missing potentially relevant studies by the search strategy, the reference lists of retrieved articles were also manually screened. A restriction to human studies and references published in English is imposed in the references selection. The review, opinion and editorial references as well as mechanistic studies were not considered. By reviewing titles, abstracts, and a full text of all citations identified with database searches, the potentially relevant references were identified on the basis of the following inclusion criteria.

\subsection{Inclusion Criteria}

Studies were included if they met the following criteria. The individual studies were examined and determined to be of sound science. For the meta-analysis of the B vitamins levels in PD patients, it was required that the included studies clearly provided the mean and standard deviation (SD) values of B vitamins levels for PD patients and matched controls. For the meta-analysis of the dietary intake of $\mathrm{B}$ vitamins and risk of $\mathrm{PD}$, the odds ratios (ORs) or relative risks (RRs) or hazard ratios (HRs) with $95 \%$ confidence intervals (CI) of PD risk should be clearly provided. 


\subsection{Statistical Analysis}

With prespecified data extraction tables, data was extracted from the included studies about the characteristics of study populations, B vitamin levels or PD risk and adjusting factors. The extracted data was used to obtain the corresponding standardized mean difference (SMD) and 95\% CI of B vitamins levels in PD patients and controls, or OR and 95\% CI of PD risk. Possible statistical heterogeneity between the eligible studies was assessed using the $I^{2}$ statistic. The random-effect model was used to pool the SMD of B vitamins levels and OR of PD risk. All calculations were done with the Stata 12.0 statistical software (STATA Corp., College Station, TX, USA).

\section{Results}

Figure 1 showed the literature selection and identification flow diagram. Our literature search resulted in 552 initial hits and 10 eligible studies finally included in the meta-analysis [17-26]. Seven studies including 10 study populations [17-23] provided data on folate and vitamin B12 levels in PD patients and controls, among which, 8 study populations were levodopa treated and 2 were levodopa untreated. 3 studies provided data on dietary intakes of B vitamins and PD risk [24-26].

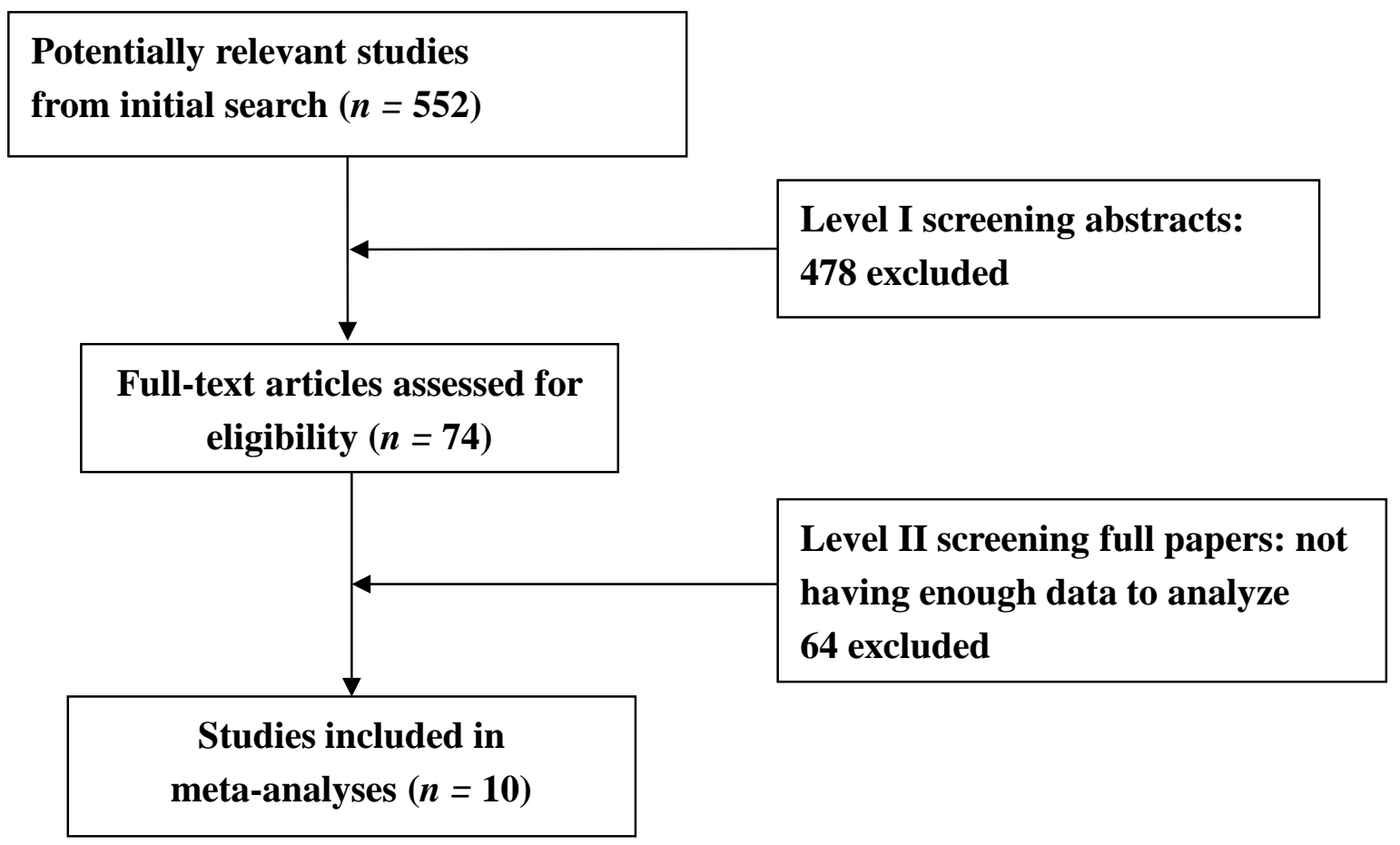

Figure 1. Search strategy for meta-analysis.

Table 1 listed the study and population characteristics of folate levels in PD patients and controls. According to the pooled data as shown in Figure 2, no obvious difference in folate level was found between levodopa treated or untreated patients and controls. Similar analysis on the basis of the extracted data in Table 2 indicated that vitamin B12 level was lower in both levodopa treated (summary SMD $=-0.35,95 \% \mathrm{CI}=(-0.50,-0.21)$ ) and untreated (summary $\mathrm{SMD}=-0.53,95 \%$ $\mathrm{CI}=(-0.86,-0.19)$, Figure 3$) \mathrm{PD}$ patients than matched controls with low statistical heterogeneity. At present, there is not enough data of vitamin B6 levels to perform meta-analysis study. 
There were three studies included in the meta-analysis of the association between dietary intakes of folate, vitamin B6 and vitamin B12 and risk of PD (Table 3). According to the pooled OR, dietary intakes of folate and vitamin B12 were not associated with lower PD risks $(\mathrm{OR}=1.01,95 \% \mathrm{CI}=(0.68,1.34)$, Figure 4; and $\mathrm{OR}=1.05,95 \% \mathrm{CI}=(0.76,1.35)$, Figure 5$)$. In comparison, dietary intake of vitamin B6 was related to decreased risk of developing $\mathrm{PD}(\mathrm{OR}=0.65,95 \% \mathrm{CI}=(0.30,1.01)$, Figure 6) with moderate statistical heterogeneity.

Table 1. Characteristics of studies of folate levels (nmol/L) in levodopa treated and untreated Parkinson's disease (PD) patients and controls.

\begin{tabular}{|c|c|c|c|c|c|c|c|}
\hline \multirow[t]{2}{*}{ References } & \multirow[t]{2}{*}{ Subgroup } & \multicolumn{2}{|c|}{ Mean age (years) } & \multicolumn{2}{|r|}{$n$} & \multicolumn{2}{|c|}{$\begin{array}{c}\text { Folate levels }(\mathrm{nmol} / \mathrm{L}) \\
(\text { Mean } \pm \text { SD })\end{array}$} \\
\hline & & PD & Control & PD & Control & PD & Control \\
\hline $\begin{array}{l}\text { Miller et al. } \\
2003 \text { [17] }\end{array}$ & Treated & $64 \pm 9$ & $60 \pm 10$ & 20 & 20 & $12.8 \pm 11.6$ & $12.6 \pm 10.8$ \\
\hline $\begin{array}{c}\text { Religa et al. } \\
2006[18]\end{array}$ & Treated & $70.5 \pm 7.57$ & $71.2 \pm 6.0$ & 99 & 100 & $20.87 \pm 9.58$ & $17.13 \pm 12.21$ \\
\hline $\begin{array}{l}\text { Triantafyllou } \\
\text { et al. } 2008 \text { [19] }\end{array}$ & Treated & $70.1 \pm 8.0$ & $69.6 \pm 8.1$ & 111 & 93 & $9.92 \pm 5.17$ & $12.35 \pm 6.57$ \\
\hline $\begin{array}{c}\text { Shin et al. } 2009 \\
{[20]}\end{array}$ & Treated & $63.5 \pm 7.8$ & $65.4 \pm 7.8$ & 33 & 41 & $19.26 \pm 9.06$ & $23.11 \pm 10.87$ \\
\hline $\begin{array}{l}\text { Yuan et al. } \\
2009[21]\end{array}$ & Treated & $71.83 \pm 10.34$ & $69.95 \pm 8.46$ & 48 & 110 & $18.28 \pm 10.8$ & $20.37 \pm 10.33$ \\
\hline $\begin{array}{l}\text { Białecka } \\
\text { et al. } 2012 \text { [22] }\end{array}$ & Treated & $64.4 \pm 10.1$ & $64.8 \pm 9.6$ & 320 & 254 & $20.16 \pm 9.52$ & $21.52 \pm 9.28$ \\
\hline $\begin{array}{c}\text { Song et al. } 2013 \\
\text { [23] }\end{array}$ & Treated & $66.45 \pm 6.60$ & $66.23 \pm 11.83$ & 33 & 48 & $34.46 \pm 25.69$ & $38.54 \pm 33.57$ \\
\hline $\begin{array}{c}\text { Song et al. } 2013 \\
\text { [23] }\end{array}$ & Treated & $70.50 \pm 6.75$ & $66.23 \pm 11.83$ & 28 & 48 & $29.47 \pm 27.21$ & $38.54 \pm 33.57$ \\
\hline $\begin{array}{c}\text { Religa et al. } \\
2006[18]\end{array}$ & Untreated & $66.0 \pm 7.11$ & $71.2 \pm 6.0$ & 15 & 100 & $16.88 \pm 6.39$ & $17.13 \pm 12.21$ \\
\hline $\begin{array}{l}\text { Yuan et al. } \\
2009[21]\end{array}$ & Untreated & $70.57 \pm 9.09$ & $69.95 \pm 8.46$ & 28 & 110 & $20.87 \pm 8.11$ & $20.37 \pm 10.33$ \\
\hline
\end{tabular}




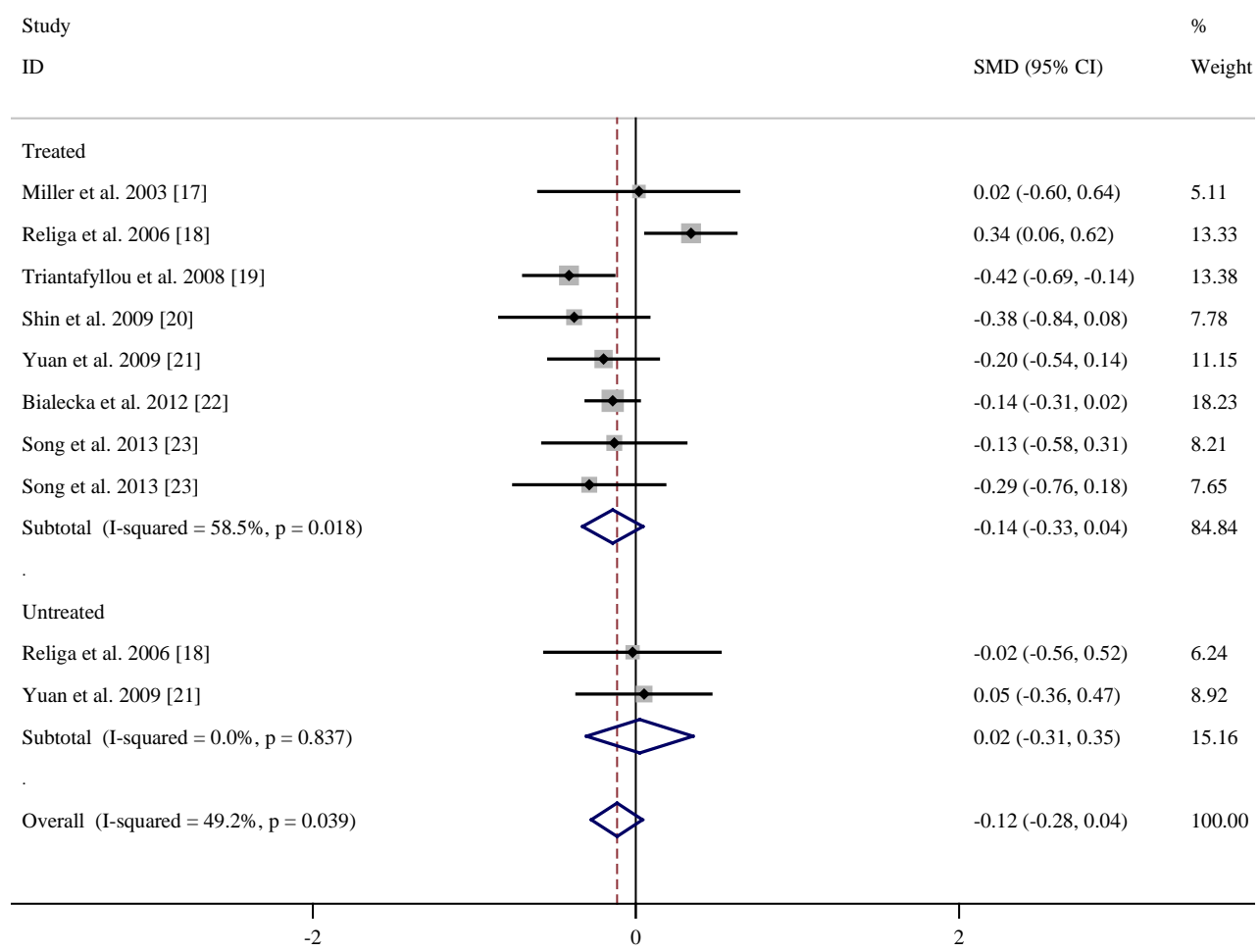

Figure 2. Pooled estimate of standardized mean difference (SMD) and 95\% confidence interval (CI) of Parkinson's disease (PD) and folate level in plasma.

Table 2. Summary of studies regarding plasma vitamin B12 level (pmol/L) in in levodopa treated and untreated PD patients and controls.

\begin{tabular}{|c|c|c|c|c|c|c|c|}
\hline \multirow[t]{2}{*}{ References } & \multirow[t]{2}{*}{ Subgroup } & \multicolumn{2}{|c|}{ Mean age (years) } & \multicolumn{2}{|r|}{$n$} & \multicolumn{2}{|c|}{$\begin{array}{c}\text { Vitamin B12 levels (pmol/L) } \\
(\text { Mean } \pm \text { SD) }\end{array}$} \\
\hline & & PD & Control & PD & Control & PD & Control \\
\hline $\begin{array}{l}\text { Miller et al. } \\
2003 \text { [17] }\end{array}$ & Treated & $64 \pm 9$ & $60 \pm 10$ & 20 & 20 & $375 \pm 167$ & $464 \pm 249$ \\
\hline $\begin{array}{l}\text { Religa et al. } \\
2006[18]\end{array}$ & Treated & $70.5 \pm 7.57$ & $71.2 \pm 6.0$ & 99 & 100 & $241.04 \pm 129.04$ & $17.13 \pm 12.21$ \\
\hline $\begin{array}{c}\text { Triantafyllou et al. } \\
\text { 2008 [19] }\end{array}$ & Treated & $70.1 \pm 8.0$ & $69.6 \pm 8.1$ & 111 & 93 & $216.03 \pm 90.5$ & $283.54 \pm 114.43$ \\
\hline $\begin{array}{l}\text { Shin et al. } \\
2009 \text { [20] }\end{array}$ & Treated & $63.5 \pm 7.8$ & $65.4 \pm 7.8$ & 33 & 41 & $528.71 \pm 299.70$ & $651.93 \pm 236.25$ \\
\hline $\begin{array}{c}\text { Yuan et al. } 2009 \\
\text { [21] }\end{array}$ & Treated & $71.83 \pm 10.34$ & $69.95 \pm 8.46$ & 48 & 110 & $354.76 \pm 191.32$ & $362.46 \pm 135.82$ \\
\hline $\begin{array}{l}\text { Białecka et al. } \\
2012[22]\end{array}$ & Treated & $64.4 \pm 10.1$ & $64.8 \pm 9.6$ & 320 & 254 & $244.95 \pm 104.77$ & $295.12 \pm 150.51$ \\
\hline $\begin{array}{c}\text { Song et al. } 2013 \\
\text { [23] }\end{array}$ & Treated & $66.45 \pm 6.60$ & $66.23 \pm 11.83$ & 33 & 48 & $473.61 \pm 220.53$ & $480.53 \pm 239.45$ \\
\hline
\end{tabular}


Table 2. Cont.

\begin{tabular}{|c|c|c|c|c|c|c|c|}
\hline \multirow{2}{*}{ References } & \multirow[t]{2}{*}{ Subgroup } & \multicolumn{2}{|c|}{ Mean age (years) } & \multicolumn{2}{|r|}{$n$} & \multicolumn{2}{|c|}{$\begin{array}{c}\text { Vitamin B12 levels }(\mathrm{pmol} / \mathrm{L}) \\
(\text { Mean } \pm \text { SD) }\end{array}$} \\
\hline & & PD & Control & PD & Control & PD & Control \\
\hline $\begin{array}{c}\text { Song et al. } 2013 \\
\text { [23] }\end{array}$ & Treated & $70.50 \pm 6.75$ & $66.23 \pm 11.83$ & 28 & 48 & $428.84 \pm 265.56$ & $470.61 \pm 239.45$ \\
\hline $\begin{array}{c}\text { Religa et al. } \\
2006[18]\end{array}$ & Untreated & $66.0 \pm 7.11$ & $71.2 \pm 6.0$ & 15 & 100 & $201.42 \pm 63.82$ & $305.08 \pm 178.03$ \\
\hline $\begin{array}{l}\text { Yuan et al. } \\
2009[21]\end{array}$ & Untreated & $70.57 \pm 9.09$ & $69.95 \pm 8.46$ & 28 & 110 & $299.95 \pm 112.20$ & $362.46 \pm 135.82$ \\
\hline
\end{tabular}

PD: Parkinson's disease; SD: standard deviation.

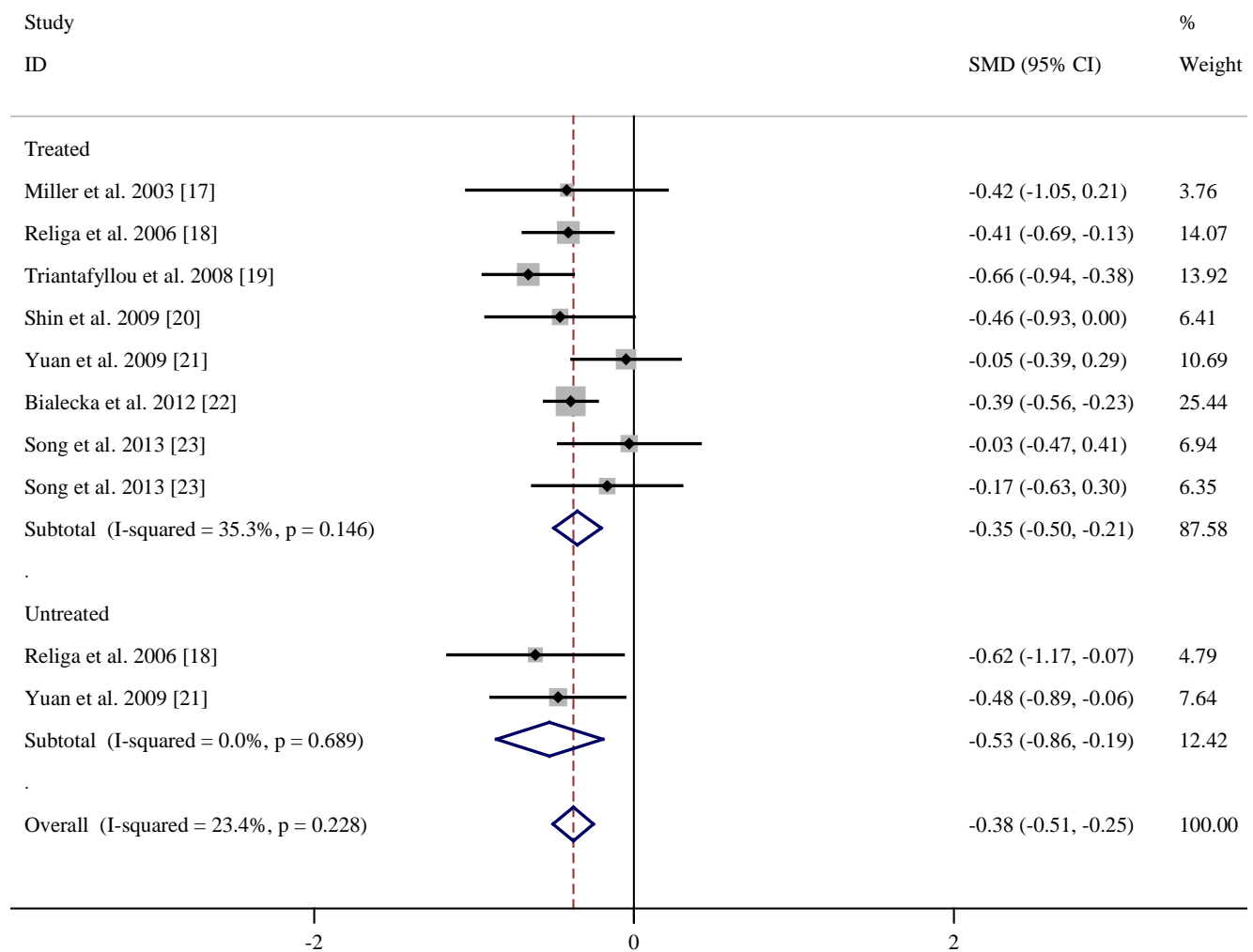

Figure 3. Pooled estimate of standardized mean difference (SMD) and 95\% confidence interval (CI) of Parkinson's disease (PD) and vitamin B12 level in plasma. 
Table 3. Summary of studies regarding dietary intakes of folate, vitamin B6 and vitamin B12 and risk of PD.

\begin{tabular}{|c|c|c|c|c|}
\hline References & $\begin{array}{l}\text { Relative risk } \\
(95 \% \mathrm{CI}) \text { for } \\
\text { folate }\end{array}$ & $\begin{array}{c}\text { Relative risk } \\
(95 \% \mathrm{CI}) \text { for } \\
\text { vitamin B6 }\end{array}$ & $\begin{array}{l}\text { Relative risk } \\
(95 \% \mathrm{CI}) \text { for } \\
\text { vitamin B12 }\end{array}$ & Adjustment \\
\hline Chen et al. 2004 [22] & $1.2(0.8,1.7)$ & $1.0(0.7,1.4)$ & $1.0(0.7,1.4)$ & $\begin{array}{l}\text { age, smoking, total energy intake } \\
\text { alcohol consumption, caffeine } \\
\text { intake, and lactose intake }\end{array}$ \\
\hline De Lau et al. 2006 [23] & $0.75(0.37,1.49)$ & $0.46(0.22,0.96)$ & $1.11(0.61,2.01)$ & age, sex, and total energy intake \\
\hline $\begin{array}{c}\text { Murakami et al. } 2010 \\
{[24]}\end{array}$ & $0.93(0.38,2.31)$ & $0.48(0.23,0.99)$ & $1.29(0.69,2.44)$ & $\begin{array}{l}\text { age, sex, region, smoking, } \\
\text { education, BMI, and dietary } \\
\text { factors, including cholesterol, } \\
\text { dietary glycaemic index, } \\
\text { vitamin E, vitamin C, } \\
\beta \text {-carotene, alcohol, caffeine } \\
\text { and Fe, and intake of other } \\
\text { B vitamins }\end{array}$ \\
\hline
\end{tabular}

PD: Parkinson's disease; CI: confidence interval.

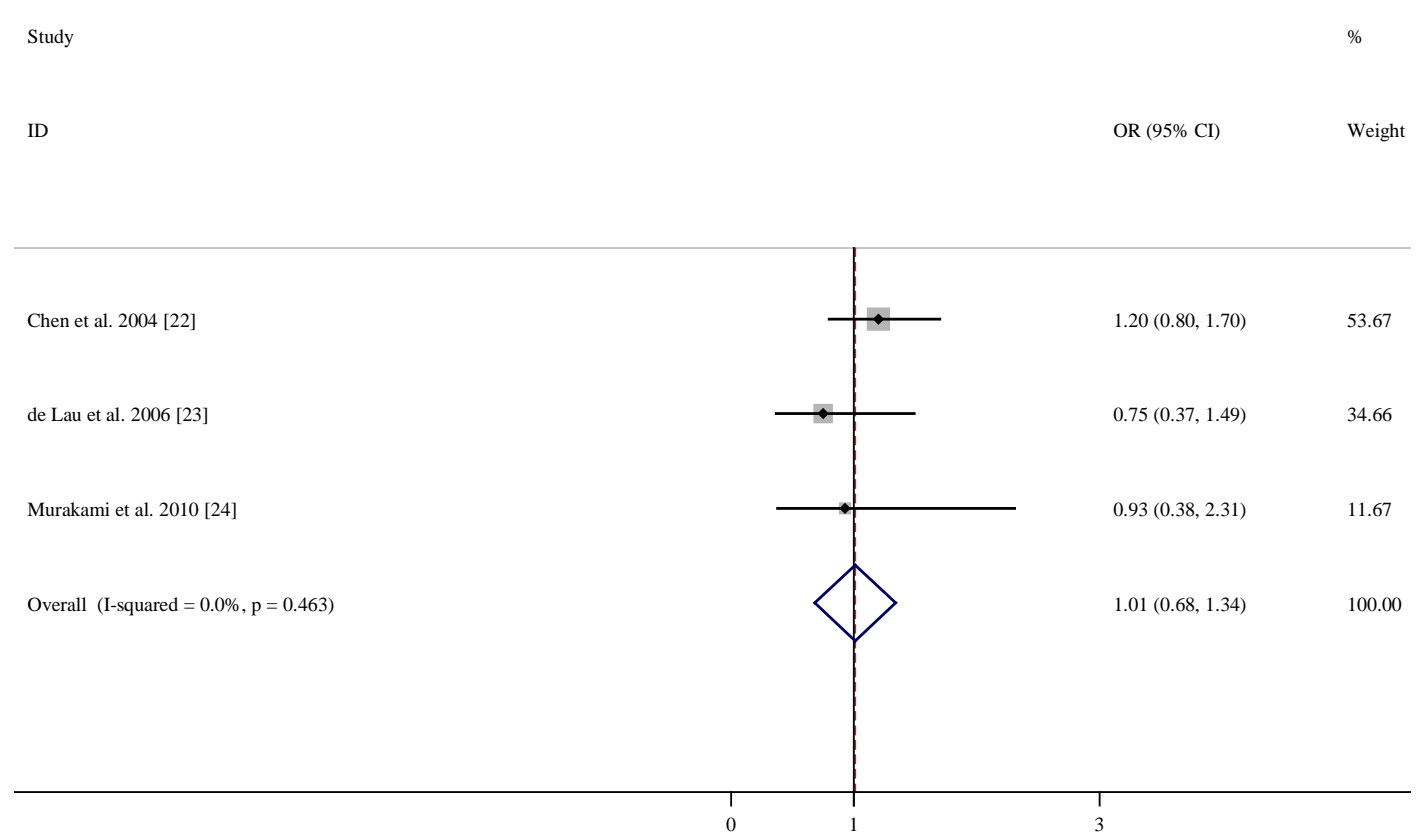

Figure 4. Forest plots of dietary intakes of folate and risk of Parkinson's disease (PD). 


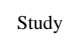

ID

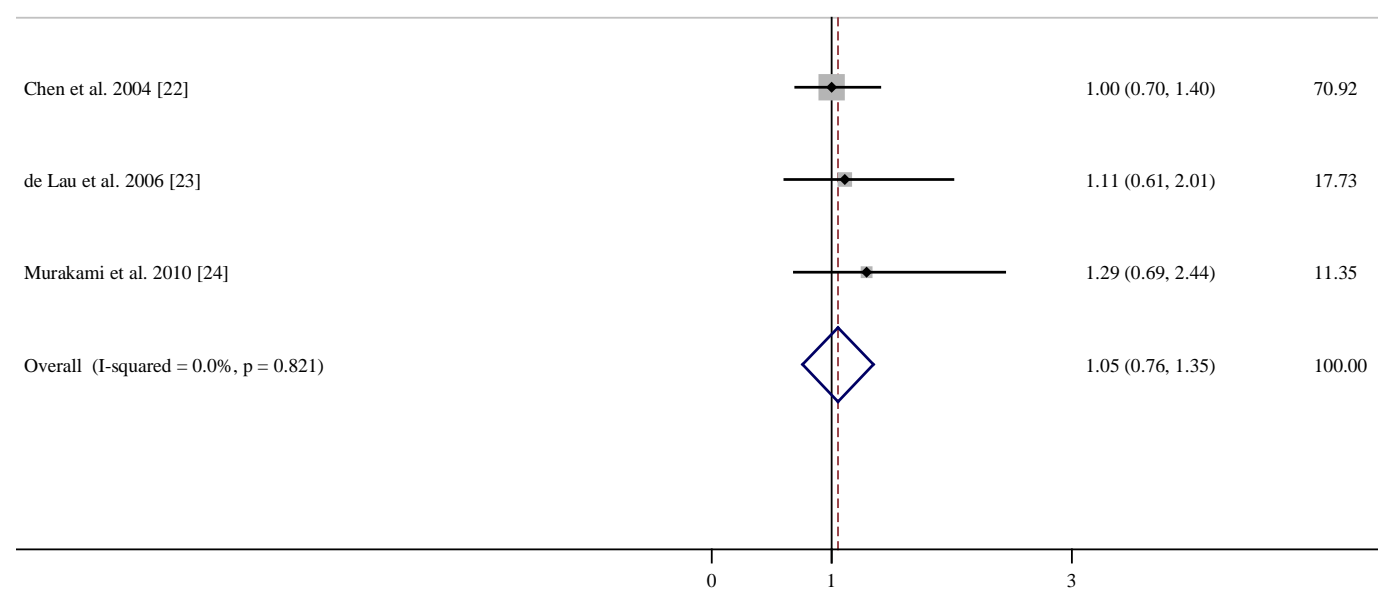

Figure 5. Forest plots of dietary intakes of vitamin B12 and risk of PD.

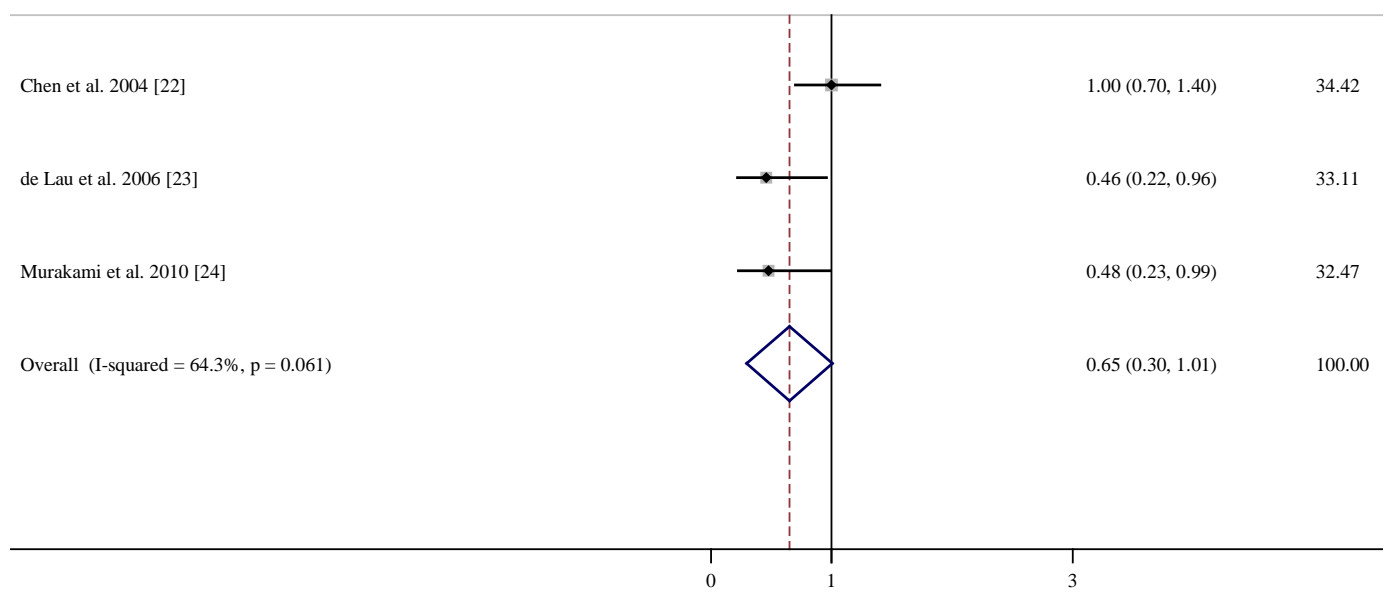

Figure 6. Forest plots of dietary intakes of vitamin B6 and risk of PD.

\section{Discussion}

In the present meta-analysis, the available data indicated no obvious difference in folate level between PD patients and controls, while vitamin B12 level was lower in PD patients than matched controls. Higher dietary intake of vitamin B6 may be associated with a decreased risk of PD, while there is no evidence to support the effects of folate and vitamin B12.

Homocysteine has been found to exhibit multiple neurotoxic effects and it is rational to infer that high dietary intakes of B vitamins may lower the risk of PD by decreasing plasma homocysteine levels. The present meta-analysis on the available studies suggested that there was no significant association between dietary intake of folate and vitamin B12 and risk of PD, while high dietary intakes of vitamin B6 was associated with decreased risk of PD. Thus, it is speculated that there may exist an alternative 
mechanism underlying the protective effects of vitamin B6 for PD. Oxidative stress has been widely accepted to play an important role in the pathogenesis of PD [4,5]. Besides its function as a cofactor, vitamin B6 is reported to possess antioxidant activity [27,28]. Pyridoxine is found to exhibit singlet oxygen quench capacity comparable with those of highly efficient antioxidants vitamins $\mathrm{C}$ and $\mathrm{E}$ [27]. It was demonstrated that vitamin B6 deficiency can lead to oxidative stress in rat liver and heart, while vitamin B6 supplementation can alleviate oxidative stress [29,30]. For instance, antioxidant activity of vitamin B6 can delay homocysteine-induced atherosclerosis in rats [31]. Moreover, it was reported that in stroke disease B vitamins supplementation may possess antioxidant and anti-inflammatory activities independent of the hypothesized homocysteine-lowering activity [32]. Thus, based on these evidences, it is proposed that besides regulating homocysteine levels the antioxidant potential of vitamin B6 may lower the risk of PD through inhibiting oxidative stress.

Several limitations of the present study warrant mention. First, the number of eligible studies is limited, especially for the analysis in the B vitamins levels in levodopa untreated PD patients. Second, the B vitamins dietary intakes are based on self-administered diet questionnaire, and the dosages varied in the included studies, which may potentially affect the results, and studies with control of people's diet are recommended. Third, only studies published in English were included in the analysis.

To summarize, available data indicated that that PD patients had lower level of vitamin B12 and similar level of folate compared with controls. High dietary intake of vitamin B6 may be associated with a decreased risk of PD, while no obvious association was observed for dietary intake of folate and vitamin B12 and risk of PD. As the number of included studies is limited, more studies are warranted to confirm the findings and elucidate the mechanisms underlying these associations.

\section{Acknowledgments}

This work was supported by the National Natural Science Foundation of China (Grant No. 30800184), Shandong Provincial Natural Science Foundation for Excellent Young Scholars (Grant No. ZR2015JL010) and Shandong Provincial Natural Science Foundation (Grant No. ZR2014CL008).

\section{Conflicts of Interest}

The author declare no conflict of interest.

\section{References}

1. Lees, A.J.; Hardy, J.; Revesz, T. Parkinson's disease. Lancet 2009, 373, 2055-2066. [CrossRef]

2. Connolly, B.S.; Lang, A.E. Pharmacological treatment of Parkinson disease: A review. JAMA 2014, 311, 1670-1683. [CrossRef] [PubMed]

3. De Lau, L.M.; Breteler, M.M. Epidemiology of Parkinson's disease. Lancet Neurol. 2006, 5, 525-535. [CrossRef]

4. Jenner, P. Oxidative stress in Parkinson's disease. Ann. Neurol. 2003, 53, S26-S36. [CrossRef] [PubMed]

5. Dias, V.; Junn, E.; Mouradian, M.M. The role of oxidative stress in Parkinson's disease. J. Parkinsons. Dis. 2013, 3, 461-491. [PubMed] 
6. Seshadri, S.; Beiser, A.; Selhub, J.; Jacques, P.F.; Rosenberg, I.H.; D’Agostino, R.B.; Wilson, P.W.; Wolf, P.A. Plasma homocysteine as a risk factor for dementia and Alzheimer's disease. N. Engl. J. Med. 2002, 346, 476-483. [CrossRef] [PubMed]

7. Prins, N.D.; den Heijer, T.; Hofman, A.; Koudstaal, P.J.; Jolles, J.; Clarke, R.; Breteler, M.M. Homocysteine and cognitive function in the elderly: The Rotterdam Scan Study. Neurology 2002, 59, 1375-1380. [CrossRef] [PubMed]

8. Kuhn, W.; Roebroek, R.; Blom, H.; van Oppenraaij, D.; Muller, T. Hyperhomocysteinaemia in Parkinson's disease. J. Neurol. 1998, 245, 811-812. [CrossRef] [PubMed]

9. Postuma, R.B.; Lang, A. Homocysteine and levodopa. Should parkinson disease patients receive preventative therapy? Neurology 2004, 63, 886-891. [CrossRef] [PubMed]

10. Müller, T. Role of homocysteine in the treatment of Parkinson's disease. Expert Rev. Neurother. 2008, 8, 957-967. [CrossRef] [PubMed]

11. Papazisis, K.; Kyriazis, G.; Kiosseoglou, G.; Kazis, A. Endothelial function markers in parkinsonian patients with hyperhomocysteinemia. J. Clin. Neurosci. 2005, 12, 669-672.

12. Todorović, Z.; Dzoljić, E.; Novaković, I.; Mirković, D.; Stojanović, R.; Nesić, Z.; Krajinović, M.; Prostran, M.; Kostić, V. Homocysteine serum levels and MTHFR C677T genotype in patients with Parkinson's disease, with and without levodopa therapy. J. Neurol. Sci. 2006, 248, 56-61. [CrossRef] [PubMed]

13. Rodriguez-Oroz, M.C.; Lage, P.M.; Sanchez-Mut, J.; Lamet, I.; Pagonabarraga, J.; Toledo, J.B.; García-Garcia, D.; Clavero, P.; Samaranch, L.; Irurzun, C.; et al. Homocysteine and cognitive impairment in Parkinson's disease: A biochemical, neuroimaging, and genetic study. Mov. Disord. 2009, 24, 1437-1444. [CrossRef] [PubMed]

14. Duan, W.; Ladenheim, B.; Cutler, R.G.; Kruman, I.I.; Cadet, J.L.; Mattson, M.P. Dietary folate deficiency anded elevated homocysteine levels endanger dopaminergic neurons in models of Parkinson's disease. J. Neurochem. 2002, 80, 101-110. [CrossRef] [PubMed]

15. Kruman, I.I.; Culmsee, C.; Chan, S.L.; Kruman, Y.; Guo, Z.; Penix, L.; Mattson, M.P. Homocysteine elicits a DNA damage response in neurons that promotes apoptosis and hypersensitivity to excitotoxicity. J. Neurosci. 2000, 20, 6920-6926. [PubMed]

16. Lipton, S.A.; Kim, W.K.; Choi, Y.B.; Kumar, S.; D’Emilia, D.M.; Rayudu, P.V.; Arnelle, D.R.; Stamler, J.S. Neurotoxicity associated with dual actions of homocysteine at the N-methyl-D-aspartate receptor. Proc. Natl. Acad. Sci. USA 1997, 94, 5923-5928. [CrossRef] [PubMed]

17. Miller, J.W.; Selhub, J.; Nadeau, M.R.; Thomas, C.A.; Feldman, R.G.; Wolf, P.A. Effect of L-dopa on plasma homocysteine in PD patients: Relationship to B-vitamin status. Neurology 2003, 60, 1125-1129. [CrossRef] [PubMed]

18. Religa, D.; Czyzewski, K.; Styczynska, M.; Peplonska, B.; Lokk, J.; Chodakowska-Zebrowska, M.; Stepien, K.; Winblad, B.; Barcikowska, M. Hyperhomocysteinemia and methylenetetrahydrofolate reductase polymorphism in patients with Parkinson's disease. Neurosci. Lett. 2006, 404, 56-60. [CrossRef] [PubMed] 
19. Triantafyllou, N.I.; Nikolaou, C.; Boufidou, F.; Angelopoulos, E.; Rentzos, M.; Kararizou, E.; Evangelopoulos, M.E.; Vassilopoulos, D. Folate and vitamin B12 levels in levodopa-treated Parkinson's disease patients: Their relationship to clinical manifestations, mood and cognition. Parkinsonism Relat. Disord. 2008, 14, 321-325. [CrossRef] [PubMed]

20. Shin, H.W.; Sohn, Y.H. Hyperhomocysteinemia in patients with Parkinson's disease and relationship to vitamin B level. J. Mov. Disord. 2009, 2, 33-36. [CrossRef] [PubMed]

21. Yuan, R.Y.; Sheu, J.J.; Yu, J.M.; Hu, C.J.; Tseng, I.J.; Ho, C.S.; Yeh, C.Y.; Hung, Y.L.; Chiang, T.R. Methylenetetrahydrofolate reductase polymorphisms and plasma homocysteine in levodopa-treated and non-treated Parkinson's disease patients. J. Neurol. Sci. 2009, 287, 64-68. [CrossRef] [PubMed]

22. Białecka, M.; Kurzawski, M.; Roszmann, A.; Robowski, P.; Sitek, E.J.; Honczarenko, K.; Gorzkowska, A.; Budrewicz, S.; Mak, M.; Jarosz, M.; et al. Association of COMT, MTHFR, and SLC19A1(RFC-1) polymorphisms with homocysteine blood levels and cognitive impairment in Parkinson's disease. Pharmacogenet Genomics 2012, 22, 716-724. [CrossRef] [PubMed]

23. Song, I.U.; Kim, J.S.; Park, I.S.; Kim, Y.D.; Cho, H.J.; Chung, S.W.; Lee, K.S. Clinical significance of homocysteine (hcy) on dementia in Parkinson's disease (PD). Arch. Gerontol. Geriatr. 2013, 57, 288-291. [CrossRef] [PubMed]

24. Chen, H.; Zhang, S.M.; Schwarzschild, M.A.; Hernán, M.A.; Logroscino, G.; Willett, W.C.; Ascherio, A. Folate intake and risk of Parkinson's disease. Am. J. Epidemiol. 2004, 160, 368-375. [CrossRef] [PubMed]

25. De Lau, L.M.; Koudstaal, P.J.; Witteman, J.C.; Hofman, A.; Breteler, M.M. Dietary folate, vitamin B12, and vitamin B6 and the risk of Parkinson disease. Neurology 2006, 67, 315-318. [CrossRef] [PubMed]

26. Murakami, K.; Miyake, Y.; Sasaki, S.; Tanaka, K.; Fukushima, W.; Kiyohara, C.; Tsuboi, Y.; Yamada, T.; Oeda, T.; Miki, T.; et al. Dietary intake of folate, vitamin B6, vitamin B12 and riboflavin and risk of Parkinson's disease: A case-control study in Japan. Br. J. Nutr. 2010, 104, 757-764. [CrossRef] [PubMed]

27. Ehrenshaft, M.; Bilski, P.; Li, M.Y.; Chignell, C.F.; Daub, M. A highly conserved sequence is a novel gene involved in de novo vitamin B6 biosynthesis. Proc. Natl. Acad. Sci. USA 1999, 96, 9374-9378. [CrossRef] [PubMed]

28. Stocker, P.; Lesgards, J.F.; Vidal, N.; Chalier, F.; Prost, M. ESR study of a biological assay on whole blood: Antioxidant efficiency of various vitamins. Biochim. Biophys. Acta 2003, 1621, 1-8. [CrossRef]

29. Cabrini, L.; Bergami, R.; Fiorentini, D.; Marchetti, M.; Landi, L.; Tolomelli, B. Vitamin B6 deficiency affects antioxidant defences in rat liver and heart. Biochem. Mol. Biol. Int. 1998, 46, 689-697. [CrossRef] [PubMed]

30. Mahfouz, M.M.; Kummerow, F.A. Vitamin C or vitamin B6 supplementation prevent the oxidative stress and decrease of prostacyclin generation in homocysteinemic rats. Int. J. Biochem. Cell Biol. 2004, 36, 1919-1932. [CrossRef] [PubMed] 
31. Endo, N.; Nishiyama, K.; Otsuka, A.; Kanouchi, H.; Taga, M.; Oka, T. Antioxidant activity of vitamin B6 delays homocysteine-induced atherosclerosis in rats. Br. J. Nutr. 2006, 95, 1088-1093. [CrossRef] [PubMed]

32. Ullegaddi, R.; Powers, H.J.; Gariballa, S.E. B-group vitamin supplementation mitigates oxidative damage after acute ischemic stroke. Clin. Sci. 2004, 107, 477-484. [CrossRef] [PubMed]

(C) 2015 by the author; licensee MDPI, Basel, Switzerland. This article is an open access article distributed under the terms and conditions of the Creative Commons Attribution license (http://creativecommons.org/licenses/by/4.0/). 